\title{
Environmental Management Accounting Model on the Basis of Environmental Management System in Leather Industry
}

\author{
Marzie Hatef Jalil, Mahsa Narimani Abar, and Fatemeh Dadashian
}

\begin{abstract}
Environmental management system (EMS) is a useful approach for improving the environmental function of organizations. Since the main decisions of environmental management depends on the costs and benefits of the suggested changes in the environmental behavior of the firm, Environmental management accounting (EMA) seems to be an essential and fundamental step for establishing an efficient environmental management. EMA is unfortunately most likely ignored or not enough discussed in neither management nor environmental fields, especially in developing countries. Therefore, this research aims to implement the environmental management accounting in a leather factory of Iran. Furthermore, this practical research introduces a suitable and practical model for implementation of EMA in the mentioned industry. Leather industry is considered to be a polluting industry and has harmful impacts on the environment. Thus, EMA can be quite helpful in this regard.

In summary, in this study, besides studying the EMA approaches in different industries worldwide and their implementation methods, a case study was carried out in leather industry of Iran. In the end a model for EMA implementation in leather industries was produced.
\end{abstract}

Index Terms-Accounting, environmental management accounting, environmental management system, leather industries.

\section{INTRODUCTION}

Nowadays, there are more reasons for industries to be cautious of their environmental effects of their activities and they are more willing to reduce their harmful environmental impacts. Besides dealing with their environmental concerns, they can also benefit from establishing a green approach. As an example, it can provide them with marketing advantages. Moreover, some governmental facilities are promised to environmental friendly industries. Therefore, the polluting industries have to enter environmental issues in their corporate strategy. To achieve the environmental goals, industries need to establish EMS. Other managerial tools which can be also helpful are EMA, Eco-labeling, life cycle analysis and environmental efficiency evaluation. These environmental approaches have legal implementation necessity in some developed countries.

Environmental management believes that evaluation and

Manuscript received December 14, 2014; revised April 29, 2015.

Marzie Hatef Jalil and Narimani Abar Mahsa are with the Applied Science and Technology University of Tehran, Iran (e-mail: marzie.hatef@gmail.com, mahsa.narimani@gmail.com).

Dadashian Fatemeh is with Amirkabir University of Technology, Iran (e-mail: dadashia@aut.ac.ir). monitoring of the industrial activities should aim sustainable and long-term use of resources. For achieving this goal, management should act conservatively, comprehensively and sensitively toward the environmental issues. Sustainable development which also includes environmental aspects, wants the next generations to be provided with the needed resources just like the current ones [1].

The main goals that companies follow with the implementation of EMS and EMA are mainly financial.

Cost reduction by cleaning the production process, increasing the environmental efficiency of the firm, management of environmental taxes on solid and liquid waste of polluting industries, governmental facilities, environmental certificates, loans, insurance, environmental risk management and environmental penalties are just a few issues that EMS deals with [2].

On the other hand, EMA focuses on financial issues of EMS and is considered to be necessary since EMS cannot be successful enough without accounting the costs and benefits of environmental activities.

EMA can enter environmental issues directly to the decision making process of the firm. This system refers to environment as an asset and includes the environmental costs in the regular cost categories of the firm and never separates these costs. In this regard, the expenditures caused by the polluting activities of the industry and the attempts to control or clean them are categorized in the production or service expenditures.

However, the implementation of this system cannot be possible if the firm is not able to recognize its environmental costs and expenditures in the first place. Environmental cost management and cost reduction by making an impactful relation between the costs and the activities which caused them are the main characteristics of EMA. Moreover, an environmental friendly approach can have marketing advantages for the firm. Therefore, accounting of the environmental costs and evaluation of the environmental function may play an important role in implementation of EMS, financial improvement and sustainable development of the organization as well as achieving environmental certificates and standards such as ISO 14000 standard [3].

The main goal of this research is development of a model for implementation of EMA on EMS basis in leather sector of textile industry of Iran.

\section{LiterATURE REVIEW}

This research is of a practical and developing kind. The 
data collection includes library and documental studies and also consists of a field study. The collected data of the case study were then analyzed and the model of EMA implementation was developed. During the library studies of this research, several examples of implementation of EMA in other industries from all over the world were essayed. In this regard, a 2006 EMA Model development for textile companies in Lithuania by A. Laurinkeviciute and $\mathrm{Z}$. Stasiskiene and a C. Deegan's study, Environmental Management Accounting An Introduction and Case Studies for Australia, published in 2003 as well as a study carried out by P. Kanna on corporate green accounting procedures in medium-sized textile firms in India in 2001, were the most helpful [4]-[6].

\section{RESULTS AND DISCUSSION}

Before developing the EMA model, the necessity of its development should be clear for all the people involved in the project. Therefore, the very first task to do toward an EMA establishment in the firm is gaining the acceptance of the owners and decision makers of the organization as well as the people who have influence on the decision making of the firm directly or indirectly.

The next task to be done is the basic data collection. All the accounting information as well as the environmental data of the firm should be collected and then categorized based on their characteristics and types. For example the information about the waste water would be categorized in a different category from the air pollution information. However, this needed information cannot be achieved unless EMS gets established and implemented in the firm.

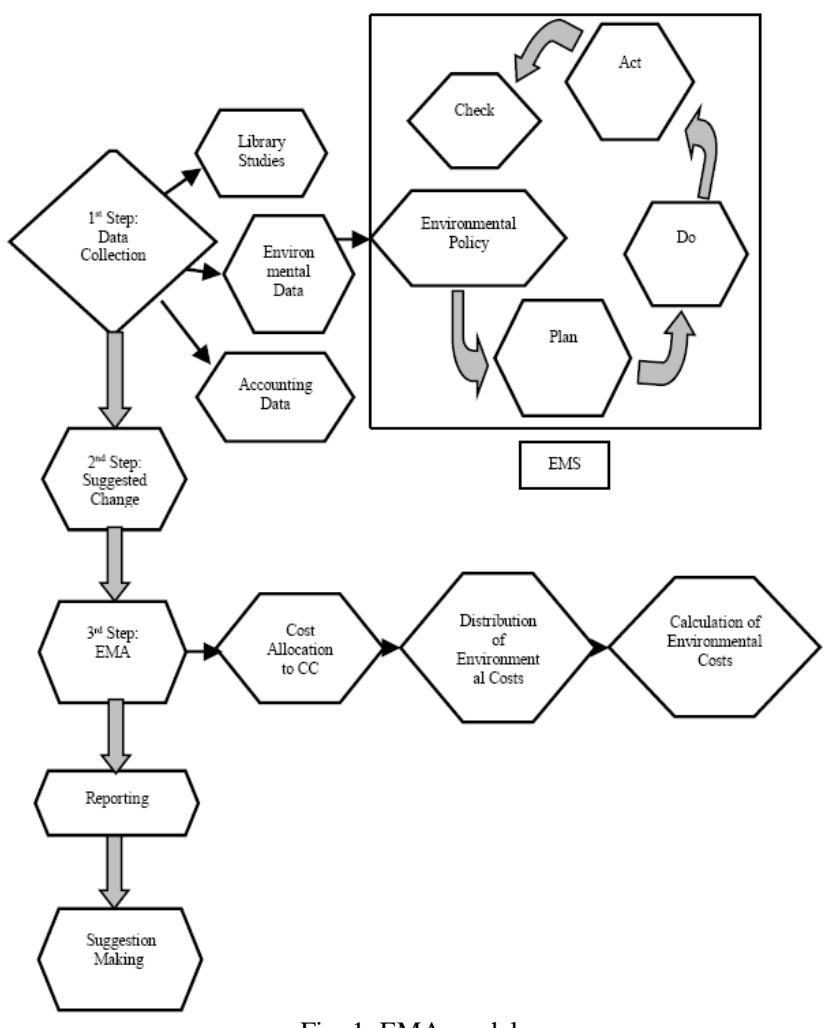

Fig. 1. EMA model.

After the data analysis, the desirable change in order to manage the harmful environmental impacts of the firm should be suggested. If the proposed change gets accepted, the information needed for that change should be collected and thus EMS gets updated constantly.

Furthermore, a comparison between the existing accounting system and EMA principles should be carried out and the lacking areas would be identified and then the changes would be made in order to be close to the ideal situation. In the end, the suitable EMA model for the firm, will be developed.

Fig. 1 indicates the suggesting EMA model of this study. This Model should be transparent and easy to follow. Complication of the process lowers the chance of EMA implementation in the industry, especially in the developing countries, where the necessity of environmental friendly activities is not fully accepted yet by the most industry owners.

A detailed explanation of the model comes directly after the Fig. 1. The whole process includes 3 main steps. Each step consists of a few activities to be done. Each of these steps and the activities will be introduced further in the paper.

\section{A. The First Step: Data Collection}

The first step, like most of the existing models, belongs to data collection and analysis.

The current situation regarding the environmental aspects of the firm should be evaluated. Library studies should be then carried out. These studies include:

\section{1) Primary information: The place of the EMA implementation}

The firm, its production process, its products, their kinds and functions should be carefully studied.

Since the case study of this paper has been carried out in leather industries, the main production processes are mentioned below:

1) Preparatory stages

2) Tanning

3) Crusting

4) Surface coating

Each of these processes consist of several sub-processes.

\section{2) Environmental data collection of the firm}

EMS can be quite helpful for environmental data collection. This system works on the basis of 4 factors: Plan, Do, Act and Check. EMS can play an important role in sustainable development of the system and therefore achieving the objectives and goals would be more probable [7].

The detailed explanation of the mentioned four factors of EMS comes below:

\section{a) Plan}

As mentioned earlier, planning is the first phase of EMS, which includes a few subjects. These subjects are as follows:

- Identification and recording of environmental impacts of the processes

The environmental review should be carried out in order to identify all the activities of the firm. For identification of the environmental impacts of these activities, some methods are recommended. For instance, by using the mass balance method, the diagram of the general process of the firm will be generated.

Incomes and outcomes of each production process of the 
firm will then be discussed; therefore, all the activities and their environmental impacts will be identified.

- Environmental knowledge evaluation

In this stage, using the existing information and data resources, a questionnaire for environmental knowledge evaluation will be designed and the staff of the firm are expected to answer it honestly. The answers received by the staff should then be categorized into 2 levels: General and Special [1].

It can be said that the workers of the production field mainly have a general knowledge of environment, whereas the managers and the people in charge of the firm are more likely aware of the environmental impacts of the firm and that's mainly because of the existence of the environmental regulations and restrictions on the industries by the national and international environmental organizations. Moreover, it can be said that due to the costly procedure of greening the production processes which also take a long time, these environmental friendly activities get mostly ignored when there is no outside push on the firm.

- Identification of the extremes using the ranking system

Different ways of ranking can be designed and provided regarding the needs of the firm. These methods are usually very simple although they are quite helpful [1]. Table I shows an example of an evaluation form. This form was filled out with accurate information of a leather factory in Iran. The results suggest that bleaching, tanning, dyeing and wetting processes of leather production have the main harmful environmental impacts. Therefore, EMS focused on these processes in its first implementation phase.

After these three stages mentioned above, the general diagram of the environmental impact evaluation of all the activities of the firm will be charted and ranked.

TABLE I: ENVIRONMENTAL RANKING FORM [7]

\begin{tabular}{|c|c|c|}
\hline $\begin{array}{l}\text { Functioning } \\
\text { processes: }\end{array}$ & \multicolumn{2}{|l|}{ Date: } \\
\hline Editor: & \multicolumn{2}{|l|}{ Number: } \\
\hline \multicolumn{3}{|c|}{ Title: Evaluation and Ranking of Environmental Impacts } \\
\hline \multicolumn{3}{|c|}{$\begin{array}{l}\text { Objective: Identification of Environmental Extremes of the firm } \\
\text { by Studying the Environmental Aspects of Processes, Products } \\
\text { and Services } \\
\text { Scope: All Processes, Products and Services } \\
\text { Pattern: } \\
\text { 1. Identification of all the processes, products and services } \\
\text { of the firm } \\
\text { 2. Supplying the flow charts of each sector including the } \\
\text { incomes and outcomes of the system (it should also } \\
\text { include the way of dealing with the waste made by } \\
\text { the system) } \\
\text { 3. Determination of the impact level of each process, } \\
\text { product or service } \\
\text { 4. Answering the following questions for each } \\
\text { environmental aspect: } \\
\text { a) Do we have the license? } \\
\text { b) Is it compatible with environmental } \\
\text { regulations? } \\
\text { c) Is there a control on it? }\end{array}$} \\
\hline $\mathbf{a}$ & $\mathbf{b}$ & $\bar{c}$ \\
\hline $\begin{array}{l}\text { YES: It should } \\
\text { not enter the } \\
\text { extreme list }\end{array}$ & $\begin{array}{l}\text { YES: It should } \\
\text { not enter the } \\
\text { extreme list }\end{array}$ & $\begin{array}{l}\text { YES: It should not enter the } \\
\text { extreme list }\end{array}$ \\
\hline $\begin{array}{l}\text { NO: It is better } \\
\text { to include it in } \\
\text { extreme list }\end{array}$ & $\begin{array}{l}\text { NO: It is better } \\
\text { to include it in } \\
\text { extreme list }\end{array}$ & $\begin{array}{l}\text { NO: It should enter the } \\
\text { extreme list }\end{array}$ \\
\hline
\end{tabular}

\begin{tabular}{|c|c|c|c|}
\hline \multicolumn{4}{|c|}{$\begin{array}{l}\text { Frequency Determination Method: } \\
\text { A: How many times does this process occur? } \\
\text { B: How many times this fault occurs during the } \\
\text { process? } \\
\text { Frequency: }(A+B) \div 2\end{array}$} \\
\hline \multicolumn{2}{|c|}{ Frequency } & \multicolumn{2}{|c|}{ Rank } \\
\hline \multicolumn{2}{|l|}{ Constantly } & \multicolumn{2}{|l|}{10} \\
\hline \multicolumn{2}{|l|}{ Once in a shift } & \multicolumn{2}{|l|}{9} \\
\hline \multicolumn{2}{|l|}{ Once in a day } & \multicolumn{2}{|l|}{8} \\
\hline \multicolumn{2}{|c|}{ Once in a week } & \multicolumn{2}{|l|}{7} \\
\hline \multicolumn{2}{|c|}{ Once in a month } & \multicolumn{2}{|l|}{6} \\
\hline \multicolumn{2}{|c|}{ Every 3 Months } & \multicolumn{2}{|l|}{5} \\
\hline \multicolumn{2}{|c|}{ Every 6 months } & \multicolumn{2}{|l|}{4} \\
\hline \multicolumn{2}{|c|}{ Once in a year } & \multicolumn{2}{|l|}{3} \\
\hline \multicolumn{2}{|c|}{ Once in a 1 to 5 years } & \multicolumn{2}{|l|}{2} \\
\hline \multicolumn{2}{|c|}{ Once in a 5 years } & \multicolumn{2}{|l|}{1} \\
\hline \multicolumn{4}{|c|}{ Determination of the grade of environmental impacts } \\
\hline \multicolumn{3}{|l|}{ Relations } & Grade \\
\hline $\begin{array}{l}\text { Execution } \\
\text { Halts }\end{array}$ & $\begin{array}{l}\text { Cause of } \\
\text { several deaths }\end{array}$ & $\begin{array}{l}\text { Constant } \\
\text { Destructive Impact }\end{array}$ & 10 \\
\hline $\begin{array}{l}\text { Relative } \\
\text { Displeasure }\end{array}$ & $\begin{array}{l}\text { One death } \\
\text { caused }\end{array}$ & $\begin{array}{l}\text { Destructive Impact } \\
\text { in a Restricted Area } \\
\text { or Time }\end{array}$ & 9 \\
\hline $\begin{array}{l}\text { Objection } \\
\text { Causing } \\
\text { Shutdown }\end{array}$ & $\begin{array}{l}\text { Causing } \\
\text { Disability }\end{array}$ & $\begin{array}{l}\text { Widespread Genetic } \\
\text { Impacts }\end{array}$ & $\overline{8}$ \\
\hline Ravage & $\begin{array}{l}\text { Severe } \\
\text { Laceration }\end{array}$ & $\begin{array}{l}\text { Restricted Genetic } \\
\text { Impacts }\end{array}$ & 7 \\
\hline $\begin{array}{l}\text { Nation or } \\
\text { Internationa } \\
1 \text { Objection }\end{array}$ & $\begin{array}{l}\text { Laceration or } \\
\text { any other } \\
\text { harmful impact } \\
\text { on health }\end{array}$ & $\begin{array}{l}\text { Wide Range of } \\
\text { Environmental } \\
\text { Impacts }\end{array}$ & 6 \\
\hline $\begin{array}{l}\text { Urban } \\
\text { Objection }\end{array}$ & $\begin{array}{l}\text { Usage } \\
\text { Restrictions }\end{array}$ & $\begin{array}{l}\text { Restricted Range of } \\
\text { Environmental } \\
\text { Impacts }\end{array}$ & 5 \\
\hline $\begin{array}{l}\text { Staff } \\
\text { Objection }\end{array}$ & $\begin{array}{l}\text { Medical } \\
\text { Counsel }\end{array}$ & $\begin{array}{l}\text { Wide Range of } \\
\text { Change on the } \\
\text { Appearance of the } \\
\text { Environment }\end{array}$ & 4 \\
\hline $\begin{array}{l}\text { Public } \\
\text { Dissatisfacti } \\
\text { on }\end{array}$ & $\begin{array}{l}\text { Minor Impact } \\
\text { on Health }\end{array}$ & $\begin{array}{l}\text { Restricted Range of } \\
\text { Change on the } \\
\text { Appearance of the } \\
\text { Environment }\end{array}$ & 3 \\
\hline $\begin{array}{l}\text { Minor } \\
\text { Dissatisfacti } \\
\text { on }\end{array}$ & Discomfort & $\begin{array}{l}\text { Minor Changes on } \\
\text { Environment }\end{array}$ & 2 \\
\hline Nothing & Nothing & Nothing & 1 \\
\hline Impact Rank= & Extremity $\times$ Frequ & ency & \\
\hline Ohictive S & ments Based c & Results & \\
\hline
\end{tabular}

- Environmental regulations and rules

At first, all the environmental regulations related to the firm's activities, products and services should be recognized and listed. Then, using a questionnaire, the situation of the firm regarding the establishment of those regulations should be studied.

- Pollution reduction suggestions and practices

After evaluation of the current environmental situation of the firm and by using the activity diagram, the main environmental problems will be recognized and some suggestions for the pollution reduction will be provided in this stage.

The main environmental concern of leather factories is their waste water and solid waste. The high level of Biological Oxygen Demand, BOD, and Chemical Oxygen Demand, COD, of their waste water is very dangerous for the environment. 
b) Do

- Organizational charts considering the environmental responsibilities and experts

An important issue in EMS as a basis for EMA implementation, is defining a position for an environmental expert in the organizational chart. It can probably be a managing position which gives the environmental issues the opportunity to influence the decision making of the firm.

Fig. 2 shows the suggested organizational chart of the studied leather factory [8], [9].

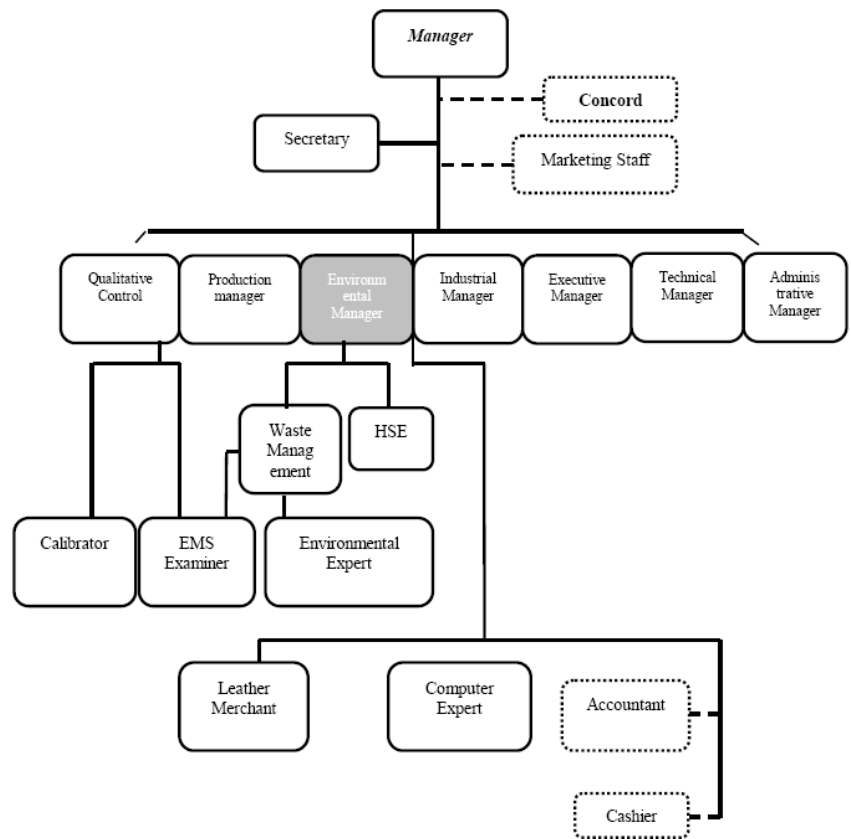

Fig. 2. Leather factory chart [8], [9].

c) Act

This stage of EMS establishment consists of different subjects. Determination of the EMS implementation monitoring system, regular reporting of the current situation of EMS, evaluation and fault recognition are some of the subjects to be dealt with in this stage.

\section{d) Check}

In reviewing, which is the last stage of EMS establishment, people who are among the decision makers of the firm or the staff who are directly a part of the EMS implementation project should be included.

Holding regular meetings is the recommended way to review the process. The discussion and results of review meetings should be documented.

\section{3) Accounting data collection}

In this stage, the financial information on recycled waste or the previous pollution reduction attempts will be gathered. The costs and benefits of the environmental activities previously done by the firm should be categorized in a table for further consideration.

Waste water purification is a way to reduce the pollution of a leather factory. The benefit achieved by establishing the waste water purification system by the studied factory was estimated 56 percent of the cost of buying the used water for the process.

Most of the environmental costs and benefits of the case study were categorized as indirect overheads.
In this stage costs recognition and categorization will be also done and then the costs of the environmental activities of the firm such as pollution prevention or fault correction will be identified and categorized. Besides, all the environmental expenditures, their variety, scope, amount and distribution will be listed. These expenditures might be generated through all the activities of the firm, from research and development to production, consumption and even recycling. Many of these costs are hidden in official and overhead costs. The evaluation of material and energy flow charts can be helpful in this regard. Environmental costs are mainly the ones related to these flow charts.

Furthermore, amount and importance level of these costs should be estimated. This can be very helpful in cost reduction and benefit enhancement. Wrong estimation of a cost may lead to a wrong importance evaluation of that cost. Clearly, the most important costs can gain more attention as a potential subject of benefit making and function improvement.

Due to what mentioned earlier, after tracking and reporting of environmental costs in this stage, environmental costs should be accurately recorded, since without listing them separately, they might be hidden or taken not seriously enough. Check-lists not only can be helpful in the cost identification but also may be useful in recognition of the benefit making opportunities. This stage is fundamental in developing an EMA system in the firm [10].

Table II indicates some general environmental costs of a factory.

TABLE II: ENVIRONMENTAL COSTS [10]

\begin{tabular}{|l|}
\hline environmental cost categories \\
\hline 1. Waste + Emission Treatment \\
\hline 1.1. Depreciation of related equipment \\
\hline 1.2. Maintenance, operating materials and services \\
\hline 1.3. Related personnel \\
\hline 1.4. Fees, taxes, charges \\
\hline 2. Prevention and environmental management \\
\hline 2.1. External services for environmental \\
\hline $\begin{array}{l}\text { 2.2. Personnel for general environmental management } \\
\text { activities }\end{array}$ \\
\hline 2.3. Research and Development \\
\hline 2.4. Extra expenditure for IPPC technologies \\
\hline 3. Material purchase value of non-product \\
\hline 3.1. Raw Materials \\
\hline 3.2. Packaging Materials \\
\hline 3.3. Auxiliary Materials \\
\hline 3.4. Operating Materials \\
\hline 3.5. Energy \\
\hline 3.6. Water \\
\hline $\begin{array}{l}\text { 4. Processing costs of non-product output } \\
\text { 5. Environmental earnings }\end{array}$ \\
\hline
\end{tabular}

After taking the first step of EMA establishment which was data collection using EMS results, the second step to be taken is suggesting the desirable change toward establishing the EMA. The explanation of this step comes below:

\section{B. The Second Step: The Suggested Change}

After taking the first step which was explained earlier, the second step belongs to the suggestion making from the experts. These experts after reviewing the current accounting 
system and the EMA principles, will identify the gaps and differences. After collecting the needed data, they look back at the production process and identify the cost centers and decide the scope and area of EMA implementation. The goals of using EMA should be very clear, since goals can motivate the management team and give the EMA system a reliable warranty of implementation.

The followings may be the main goals of EMA implementation:

1) Identification, collection, calculation and studying the materials and energy costs

2) Internal reporting and using of information of environmental costs

3) Using the EMA information for decision making of the firm

The purpose of the EMA implementation in the studied leather factory is as below:

1) Identification of environmental costs in the factory in order to protect the environment as well as cost reduction

2) Identification of the polluting processes

3) Benefit making and better financial function

Companies usually use the system of accounting based on their activities, since the accounting system of EMA also is based on the activities of the firm, the basics won't change a lot. But the important thing is that the firm should be able to identify the environmental costs correctly and use a suitable price motivator for calculating the raw price of its products. The needed changes in the accounting system of the firm will be decided considering all the factors mentioned above and should be reported to the management and then be discussed, thus any alteration suggested by the management should be considered [11].

The last step to be taken is the EMA establishment in the firm, which will be explained further below.

\section{The Third Step: EMA Establishment}

This step consists of the following subjects:

\section{1) Allocation of environmental costs to the cost centers}

After identification of environmental costs and cost centers, the allocation of these costs to the cost centers should be done. Every environmental cost indicates an impact of the firm to the environment and they are produced from a specific source in the organization. These sources of environmental effects can be considered as environmental cost centers [11].

All these environmental costs should be allocated to products, processes and organization sectors. This can be done using different methods. Accounting and cost management should be based on the functions and activities. With the help of this activity-based accounting and management system, the costs can be related to the activities which produced them and they can be also connected to the processes that are in need of these activities' outcomes, which can be helpful for allocating the costs to the products and processes accurately. In activity-based management, it is believed that the costs cannot be directly managed, but their producing activities can be. Therefore, polluting activities should be identified and their necessity would be studied.

\section{2) Calculation of environmental costs}

For calculating environmental costs as well as environmental penalties established by the government, the tables which were designed earlier in the environmental regulation and rules section can be useful. There are many different methods for calculating environmental costs, the environmental manager should decide which one to use regarding the environmental situation of the firm [4]-[11].

\begin{tabular}{|c|c|c|c|}
\hline Environmental & Account & Method & How \\
\hline $\begin{array}{l}\text { Waste and } \\
\text { stream pollution } \\
\text { reduction }\end{array}$ & $\begin{array}{l}\text { Exists } \\
\text { /New }\end{array}$ & $\begin{array}{l}\text { Counting the number } \\
\text { of containers } \\
\text { On the basis of volume } \\
\text { (cube meters) of } \\
\text { water } \\
\text { On the basis of the } \\
\text { area } \\
\text { Estimation } \\
\text { Cost center } \\
\text { Estimation based on } \\
\text { the measured } \\
\text { amount of pollution }\end{array}$ & $\begin{array}{l}\text { Analysis and } \\
\text { allocation to } \\
\text { cost centers }\end{array}$ \\
\hline $\begin{array}{l}\text { Depreciation of } \\
\text { related } \\
\text { equipment }\end{array}$ & Exists & $\begin{array}{l}\text { Counting the } \\
\text { number of } \\
\text { configuration times } \\
\text { of the machinery }\end{array}$ & $\begin{array}{l}\text { Analysis and } \\
\text { allocation to } \\
\text { cost centers }\end{array}$ \\
\hline $\begin{array}{l}\text { Maintenance, } \\
\text { operating } \\
\text { materials and } \\
\text { services }\end{array}$ & Exists & Hours of work & $\begin{array}{l}\text { Analysis and } \\
\text { allocation to } \\
\text { cost centers }\end{array}$ \\
\hline $\begin{array}{l}\text { Related } \\
\text { personnel }\end{array}$ & New & Hours of work & $\begin{array}{l}\text { Analysis and } \\
\text { allocation to } \\
\text { cost centers }\end{array}$ \\
\hline $\begin{array}{l}\text { Fees, taxes, } \\
\text { charges }\end{array}$ & Exists & $\begin{array}{l}\text { On the basis of volume } \\
\text { (cube meters) of water }\end{array}$ & $\begin{array}{l}\text { Analysis and } \\
\text { allocation to } \\
\text { cost centers }\end{array}$ \\
\hline $\begin{array}{l}\text { External } \\
\text { services for } \\
\text { environmental }\end{array}$ & Exists & Estimation & $\begin{array}{l}\text { Analysis and } \\
\text { allocation to } \\
\text { cost centers }\end{array}$ \\
\hline $\begin{array}{l}\text { Personnel for } \\
\text { general } \\
\text { environmental } \\
\text { management } \\
\text { activities }\end{array}$ & Exists & Estimation & $\begin{array}{l}\text { Analysis and } \\
\text { allocation to } \\
\text { cost centers }\end{array}$ \\
\hline $\begin{array}{l}\text { Research and } \\
\text { Development }\end{array}$ & New & $\begin{array}{l}\text { Estimated based on } \\
\text { hours of work }\end{array}$ & $\begin{array}{l}\text { Analysis and } \\
\text { allocation to } \\
\text { cost centers }\end{array}$ \\
\hline Raw Materials & New & The amount of orders & $\begin{array}{l}\text { Analysis and } \\
\text { allocation to } \\
\text { cost centers }\end{array}$ \\
\hline $\begin{array}{l}\text { Packaging } \\
\text { Materials }\end{array}$ & New & The amount of orders & $\begin{array}{l}\text { Analysis and } \\
\text { allocation to } \\
\text { cost centers }\end{array}$ \\
\hline $\begin{array}{l}\text { Auxiliary } \\
\text { Materials }\end{array}$ & New & The amount of orders & $\begin{array}{l}\text { Analysis and } \\
\text { allocation to } \\
\text { cost centers }\end{array}$ \\
\hline $\begin{array}{l}\text { Operating } \\
\text { Materials }\end{array}$ & New & The amount of orders & $\begin{array}{l}\text { Analysis and } \\
\text { allocation to } \\
\text { cost centers }\end{array}$ \\
\hline Energy & New & $\begin{array}{l}\text { Hours of energy } \\
\text { consumption }\end{array}$ & $\begin{array}{l}\text { Analysis and } \\
\text { allocation to } \\
\text { cost centers }\end{array}$ \\
\hline Water & New & $\begin{array}{l}\text { Hours of water } \\
\text { consumption }\end{array}$ & $\begin{array}{l}\text { Analysis and } \\
\text { allocation to } \\
\text { cost centers }\end{array}$ \\
\hline $\begin{array}{l}\text { Processing costs } \\
\text { of non-product } \\
\text { output }\end{array}$ & Exists & & $\begin{array}{l}\text { Analysis and } \\
\text { allocation to } \\
\text { cost centers }\end{array}$ \\
\hline $\begin{array}{l}\text { Environmental } \\
\text { earnings }\end{array}$ & Exists & & $\begin{array}{l}\text { Analysis and } \\
\text { allocation to } \\
\text { cost centers }\end{array}$ \\
\hline
\end{tabular}

Table III indicates different types of environmental costs and the best ways to calculate them. 


\section{3) Distribution of different environmental costs}

In the last stage, the environmental costs in a table template just like the Table IV should be reported to the management [4]-[6].

With completing this stage, it can be claimed that EMA system is successfully implemented in the firm.

TABLE IV: ENVIRONMENTAL MEDIA [4]-[6]

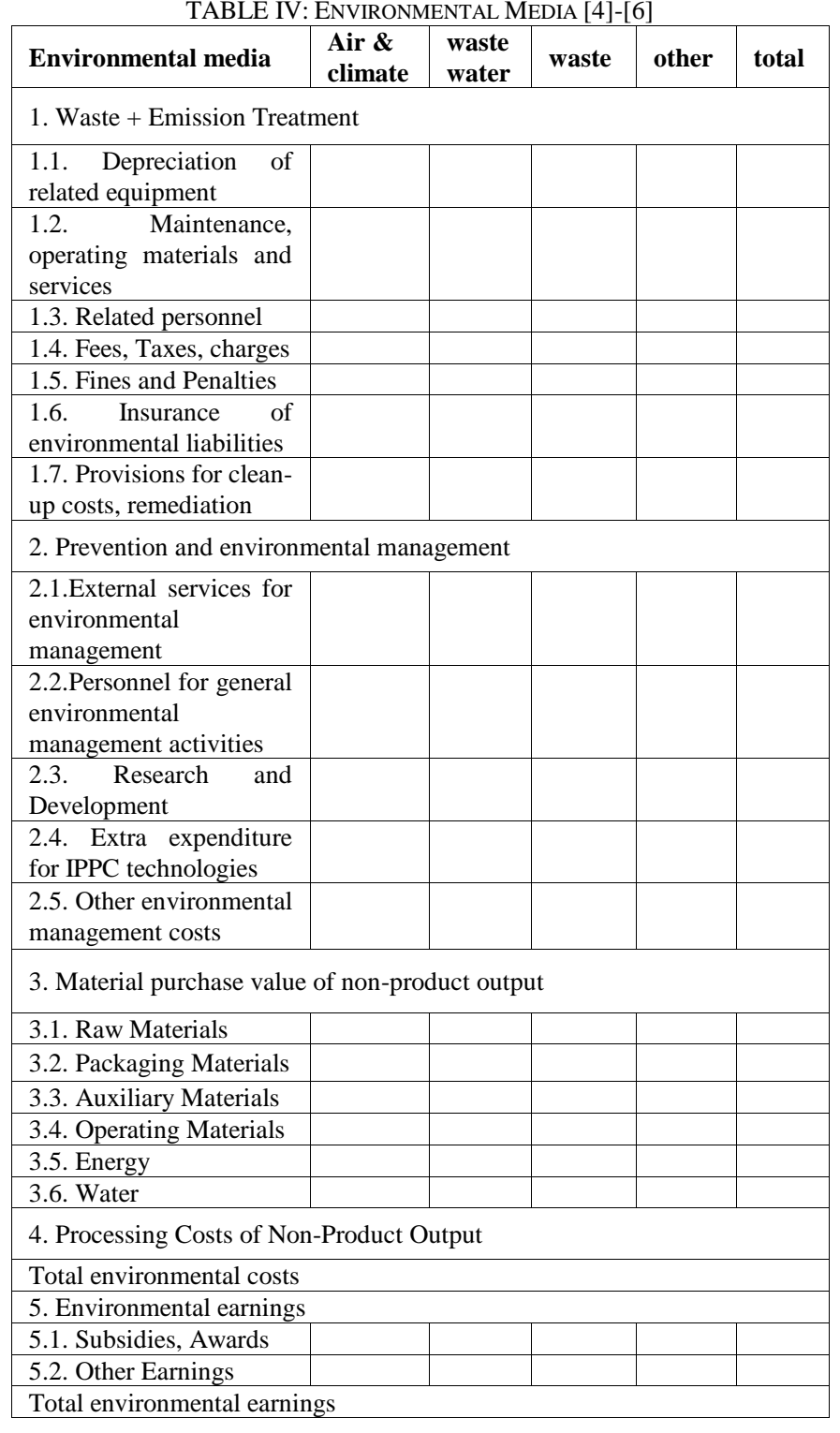

\section{CONCLUSION}

As discussed through the paper, EMA mainly focuses on identification of the materials, activities and processes and the measurement of their environmental costs burdened to the firm. This information will then be used in order to balance the reports and internal evaluation which is quite necessary for the owners of the organizations, because it can help them to be able to make the best decisions about the environmental issues.

Therefore, the main goal of environmental management accounting is to identify and declare the solutions for minimizing the harmful effects of industrial and official activities of the firm.

Furthermore, for a successful establishment of EMA in any industry, it is necessary for EMA to be able to make economic values and marketing advantages. This can be achieved by adding the EMA system to the previous accounting system. Therefore, before establishing EMA, environmental management system, EMS should be executed and able to define the environmental policy of the firm.

Regarding the case study of the paper, leather industry of Iran should follow the steps below in order to be able to establish a successful and working EMA:

1) Environmental goals for a desirable environmental situation should get determined.

2) The needed information and data should be identified. This can prevent unnecessary research and thus may save time, energy and finance.

3) Sufficient data categorization is a necessity. All the existing information and the previously done researches should be categorized. In this way, using the existing information and accessing it when needed will be much easier.

4) The existing information and the needed data of the firm should be compared.

5) Strategies in order to achieve the environmental goals should be developed and then get implemented in the firm.

In conclusion, having environmental knowledge for the accountants of organizations seem to have a great influence on the financial decisions made by the organizations, since the accountants have access to financial information of the firm and can differentiate the accurate and artificial documents.

It can be said that, if EMA get established in an organization the following results can be expected:

1) Identification of the environmental aspects of the processes

2) Reducing raw material and energy consumption and therefore cost reduction

3) Accurate cost allocation

4) Waste reduction

The obstacles for EMA establishment is mainly due to the unwillingness of the companies to reveal their environmental information and the lack of regulations regarding the transparency of the environmental costs of the companies and enterprises.

In summary, more studies should be carried out in order to make the public aware of this important issue and encourage the owners of the industries to establish EMA as an attempt to reduce the harmful effects of their activities to the environment.

\section{REFERENCES}

[1] GG 147 Guide, "Proven technology and techniques for profitable environmental improvement," Environmental Technology Best Practice Program, East Tennessee State University, 1998.

[2] P. Beveridge, "The role of the corporate center in implementing environmental management systems," Business Strategy and the Environment, vol. 9, no. 2, pp. 108-120, February 1996.

[3] M. Khoshtinat, "Environmental accounting," Journal of Accounting Research, vol. 3, pp. 10-11, March 1994.

[4] P. Khanna, "Delineation and dissemination of corporate green accounting procedures with case studies in medium sized textile," Navi Mumbai, September 2001.

[5] A. Laurinkeviciute and Z. Stasiskiene "Environmental management accounting model and its feasible integration into corporate information systems of textile companies," presented at Environmenta Research, Engineering and Management, Lithuania, September 2006. 
[6] C. Deegan, "Environmental management accounting, an introduction and case studies for Australia," National Accountant, vol. 17, no. 6, pp. 30-32, December 2001.

[7] M. Dodel, "Environmental management system in textile industry of Iran,” M.S. thesis, Dep. Textile. Eng., Amirkabir Univ., Tehran, Iran, 2013.

[8] H. Mintzberg, "Structure in fives: Designing effective organizations," Englewood Cliffs, NU: Prentice Hall, 1983.

[9] S. Atkinson, A. Schaefe, and H. HowardViney. (March 2000). Organizational structure \& effective environmental management. [Online]. Available: http://onlinelibrary.wiley.com/doi/10.1002/(SICI)1099-0836(200003/ 04)9:2\%3C108: AID-BSE236\%3E3.0.CO;2-L

[10] F. Birkin, Environmental Management Accounting, vol. 74, pp. 74-78, Feb. 1996.

[11] R. DePalma and M. Csutora, "Introducing environmental management accounting (EMA) at enterprise level," A Contribution of the UNIDO Project (Transfer of Environmentally Sound Technology (TEST) in the Danube River Basin), September 2006.

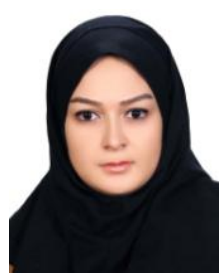

Marzie Hatef Jalil was born in Tehran, on October 7 , 1988. She is a master graduate of textile management from Amir Kabir University of Technology (Tehran Polytechnic, 2013). She has earned her B.Sc. in textile engineering in 2011 from Gilan University, Gilan Province, Iran.

She has worked for PoodIran factory as a textile engineer for 2 years after her master graduation. This textile factory produces towels and is well known in the country. Two recent articles of her named "The environmental management accounting system in the textile industry of Iran" and "Cellulose production from waste rice paddies" were published in the International Conference on New approaches in Energy Storage in 2013 and Second International Conference on Textile and Clothing at Islamic Azad University in 2011 respectively. She is now a tutor at the Applied Science and Technology University of Tehran. Environmental studies on textile industries are her main field of interest. Ms. Hatef is a member of Iran Textile Specialists Association since 2012.

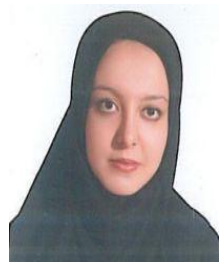

Mahsa Narimani Abar was born in Tehran on December 12, 1987. She holds a master of textile management from Amir Kabir University of Technology (Tehran Polytechnic), earned in 2013. Her B.Sc in the field of textile engineering was obtained in 2011 from the same university.

Her work experience consists of four years of teaching that was mainly associated with universities such as Amirkabir University of Technology (Tehran Polytechnic), the Applied Science and Technology University of Tehran and the University of Tehran. She is currently a tutor at the mentioned universities. She has also worked as a researcher in the field of traditional textiles of Iran at Sidaar Research Institute. Besides, she has a book under publication with Amirkabir University with the title of "Environmental strategy development in polluting industries with a practical example of textile industries of Iran". Furthermore, she has worked as an intern of teaching at a few colleges of Poland in summer and fall of 2013. Her field of interest consists of a range of subjects related to the textile art and industry. Environmental issues of textile industry have always attracted her attention, since her master thesis was based on that subject. Ms. Narimani is a member of Iran Textile Specialist Association since 2012 and has also become a member of APCBEES in January of 2015.

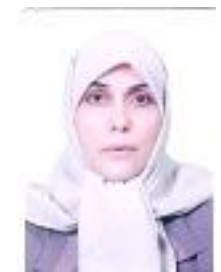

Fatmeh Dadashian was born in Tehran in 1960. She has obtained her B.Sc and M.Sc degrees in textile engineering at Amirkabir University of Technology in 1985 and 1991 respectively. She was awarded the doctor of philosophy degree in textile engineering by the University of Manchester Institutes of Science and Technology (UMIST) in 1997.

She is an associate professor of textile engineering department of Amirkabir University of Tehran. Moreover, she is a board member of University and Industry Collaboration Committee, the Environmental Engineering Group and the Technology Development Studies Center of Amirkabir University of Technology. Her work experience also consists of working as the head of Engineering Faculty of Alzahra University etc. She has published over 50 journal and 100 conference papers and several books. "Waste cotton fibers based activated carbon Optimization of process and product characterization" and "Spherical cellulose nano-particles preparation from waste cotton using agreen method" both published in 2014 are two examples of her published papers. Textile chemistry, environmental and managerial studies of textile industries are her main fields of interest. Prof. Dadashian is a member of the board of directors and the main member of Iran Textile Specialists Association. 